\title{
The Healing Poem
}

So many letters to write, so many chapters to write, so much clutter:

newspaper scraps of other lives, mugs half-full and stagnant cold, a life's work in splinters on scattered index cards, computer disks and opened books and pens everywhere; all this to put in order

and all she can think of is something that happened when she was seven, so long ago and far away that nothing is clear except fragments of choking, hurting, outrage, in a haystack.

They come out of nowhere like passing traffic, a ringing phone, a heart attack. Sometimes they flicker, then subside; sometimes they take hold like a new brutality and shake and shake until something detaches as in a death.

Little girl, are you there?

She sits calmly trying to expunge ghosts with carefully chosen, well-ordered words, but knows with a sinking sickness that this is another violation and feels herself cringing inwards to escape the made-for-television-movie triteness. Everyone is doing it these days.

Everyone is a victim, and confessions sell. 